\title{
A puzzling pneumonia in a young immunosuppressed man
}

\author{
Udana Subodhika Ratnapala, ${ }^{1}$ Alim Yucel-Finn, ${ }^{2}$ David Walbaum, ${ }^{1}$ Owen Dempsey ${ }^{3}$
}

'Department of Renal Medicine, Aberdeen Royal Infirmary, Aberdeen, UK

${ }^{2}$ Department of Radiology, Aberdeen Royal Infirmary, Aberdeen, UK

${ }^{3}$ Department of Respiratory Medicine, NHS GRAMPIAN, Aberdeen, UK

\section{Correspondence to}

Dr Udana Subodhika Ratnapala, udana752@yahoo.com

Accepted 28 March 2018

\section{DESCRIPTION}

A 34-year-old Caucasian man with chronic renal failure on peritoneal dialysis presented with a 10-day history of productive cough, worsening dyspnoea and haemoptysis. He was a non-smoker, with no previous respiratory illnesses. There was no history of foreign travel or significant domestic or environmental exposures. He was feverish and tachypnoeic with scattered crackles throughout both lungs and mildly hypoxic (oxygen saturation $92 \%$ on air). He had no peripheral oedema.

His primary renal disease was focal segmental glomerulosclerosis with frequently relapsing nephrotic syndrome since childhood. Medication included long-term immunosuppressive therapy with tacrolimus and corticosteroids $(5 \mathrm{mg}$ prednisolone), and he had received cyclophosphamide and levamisole during childhood. He had started fluoxetine hydrochloride $20 \mathrm{mg}$ daily for depression 6 months earlier. Renal transplantation was being considered.

A chest radiograph showed bilateral patchy consolidation. Pneumonia was diagnosed clinically, and he was treated with oral antibiotics and prednisolone dose doubled. Initially better, he was readmitted 2 weeks later with worsening breathlessness. He had raised inflammatory markers, worsening bilateral patchy consolidation on chest radiograph (figure 1A) and a full microbiology and vasculitis screen were negative (including respiratory viral screen, cultures of blood, sputum including mycobacteria and fungi, Pneumocystis jiroveci DNA in induced sputum, cytomegalovirus DNA in blood, HIV and Anti-neutrophil cytoplasmic antibodies (ANCA).

High resolution CT of the chest (figure 1B) showed bilateral confluent patchy consolidation, predominantly perihilar, with no definitive pneumatocoeles. Endobronchial appearances at bronchoscopy were normal and bronchoalveolar lavage contained numerous macrophages and mixed inflammatory cells, with no evidence of malignancy or infection. Pulmonary function tests confirmed normal spirometry but significantly impaired diffusing capacity for carbon monoxide (DLco) of $30 \%$. During a 6 min walking test, he could walk $480 \mathrm{~m}$ (mild impairment) with no significant desaturation below 96\%. Echocardiography showed a mildly dilated left ventricle, with moderate systolic impairment and normal right ventricular function.

Due to the CT appearances in the context of immunosuppression, $P$. jiroveci pneumonia was considered, and he was treated empirically with high-dose cotrimoxazole. Clarithromycin was added to cover atypical pneumonia pathogens. $\mathrm{He}$
Check for updates

To cite: Ratnapala US, Yucel-Finn A, Walbaum D, et al. BMJ Case Rep Published Online First: [please include Day Month Year]. doi:10.1136/bcr-2018 224827

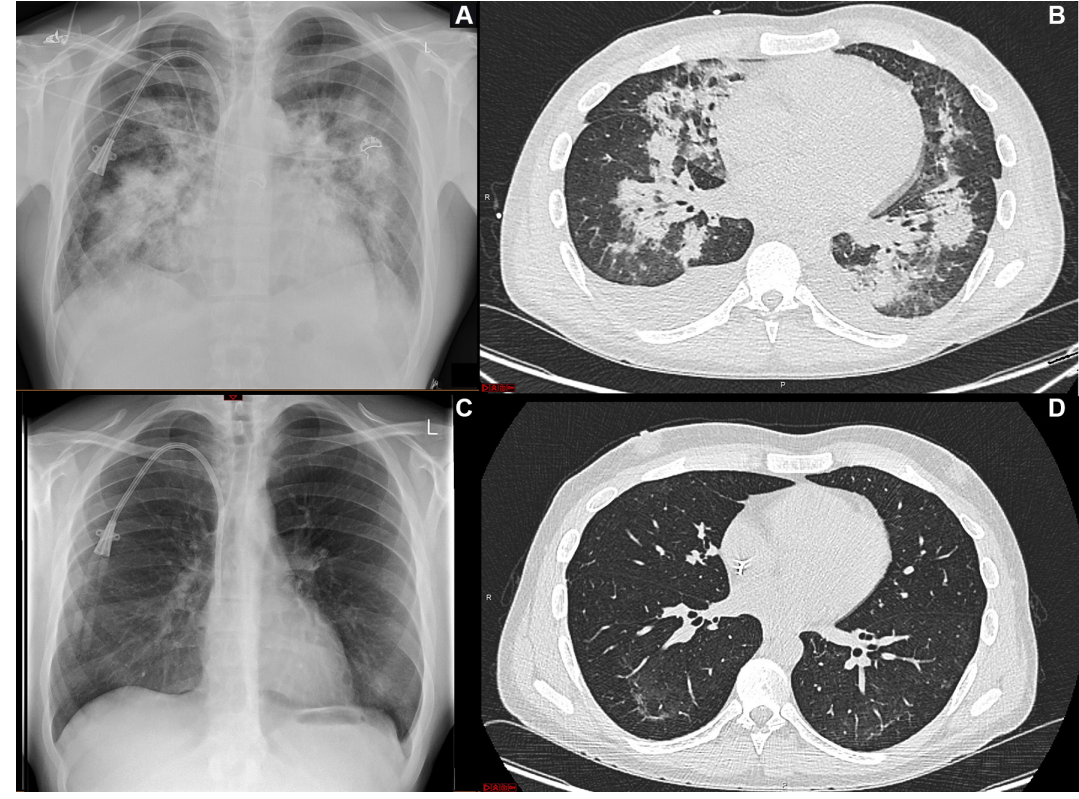

Figure 1 (A) Chest radiograph at presentation, noting bilateral perihilar areas of patchy consolidation, (B) high resolution (HR)CT at presentation confirming widespread patchy consolidation and small bilateral pleural effusions, ((C) and (D)) chest radiograph and HRCT 4 months later following cessation of fluoxetine; minor persistent ground glass change only seen on HRCT. 
was switched to intermittent haemodialysis and tacrolimus was stopped.

He failed to improve. Revisiting his history, his symptom of breathlessness had actually begun, although mildly, soon after he became depressed, and drug-induced lung disease secondary to fluoxetine was considered. This was stopped and within days he made a dramatic clinical, physiological (DLco 71\%) and radiological recovery (figure 1C,D. Due to the speed of recovery, a planned video-assisted thoracoscopic lung biopsy was therefore not performed.

Lung disease as a consequence of drug therapies may be easily missed. Patchy consolidation on a chest radiograph is, perhaps not unreasonably, often initially attributed to infection, but if it fails to improve with treatment, then alternative diagnoses should be considered. These include primary malignancy (lung carcinoma and lymphoma), secondary malignancy, vasculitis, eosinophilic pneumonia, cryptogenic organising pneumonia, connective tissue diseases and sarcoidosis. The tempo and pattern of lung disease seen with individual drug therapies are highly variable. ${ }^{1}$ Fluoxetine is a selective serotonin reuptake inhibitor characterised by antidepressant, antiobsessive-compulsive and antibulimic properties, which is one of the most commonly prescribed medications

\section{Learning points}

- A detailed drug history is essential in any patient with unexplained lung disease.

- Drug-induced lung disease is surprisingly common and clinicians should consider checking www.pneumotox.com if suspicious.

- Fluoxetine-induced pulmonary toxicity is probably underrecognised and prompt cessation can result in complete resolution. in psychiatry. ${ }^{2}$ A recent meta-analysis has reported an association with various forms of interstitial lung disease, including pneumonitis, eosinophilic pneumonia and granulomatous inflammation. ${ }^{3}$ The exact pathogenic mechanism is unclear, but some studies have suggested effects on epithelial permeability and animal studies have reported it induces bronchoconstriction and proinflammatory changes. ${ }^{4}$ There is no high quality evidence to support the use of corticosteroids in the management of fluoxetine lung toxicity, although they can be considered on an individual basis if the lung disease is slow to resolve following fluoxetine cessation.

Contributors All authors were involved in treating the patient. Initial conception and design of the study was by OD. USR was involved in acquisition of data, literature survey and manuscript drafting. AY-F obtained the radiological images. DW and OD did the critical revision of the manuscript for intellectual content and study supervision.

Funding The authors have not declared a specific grant for this research from any funding agency in the public, commercial or not-for-profit sectors.

Competing interests None declared.

Patient consent Obtained.

Provenance and peer review Not commissioned; externally peer reviewed.

(c) BMJ Publishing Group Ltd (unless otherwise stated in the text of the article) 2018. All rights reserved. No commercial use is permitted unless otherwise expressly granted.

\section{REFERENCES}

1 Camus $\mathrm{PH}$, Foucher $\mathrm{P}$, Bonniaud PH, et al. Drug-induced infiltrative lung disease. Eur Respir J Supp/ 2001;32:93s-100.

2 Kam PC, Chang GW. Selective serotonin reuptake inhibitors. Pharmacology and clinical implications in anaesthesia and critical care medicine. Anaesthesia 1997;52:982-8.

3 Deidda A, Pisanu C, Micheletto L, et al. Interstitial lung disease induced by fluoxetine: Systematic review of literature and analysis of Vigiaccess, Eudravigilance and a national pharmacovigilance database. Pharmacol Res 2017;120:294-301.

4 Capelozzi MA, Leick-Maldonado EA, Parra ER, et al. Morphological and functional determinants of fluoxetine (Prozac)-induced pulmonary disease in an experimental model. Respir Physiol Neurobiol 2007:156:171-8.

Copyright 2018 BMJ Publishing Group. All rights reserved. For permission to reuse any of this content visit

http://group.bmj.com/group/rights-licensing/permissions.

BMJ Case Report Fellows may re-use this article for personal use and teaching without any further permission.

Become a Fellow of BMJ Case Reports today and you can:

- Submit as many cases as you like

- Enjoy fast sympathetic peer review and rapid publication of accepted articles

- Access all the published articles

Re-use any of the published material for personal use and teaching without further permission

For information on Institutional Fellowships contact consortiasales@bmjgroup.com

Visit casereports.bmj.com for more articles like this and to become a Fellow 